\title{
Privatization by Auction: Determinants of Asset Prices in Kosovo
}

\author{
Petrit Gashi \\ Associate Professor \\ University of Prishtina \\ Agim Ramadani \\ 10000 Prishtina \\ Republic of Kosovo \\ petrit.gashi@uni-pr.edu \\ Iraj Hashi \\ Emeritus Professor \\ Staffordshire University \\ Leek Road \\ Stoke on Trent, ST4 2DF \\ United Kingdom \\ I.Hashi@staffs.ac.uk \\ Geoff Pugh \\ Professor of Applied Economics \\ Staffordshire University \\ Leek Road \\ Stoke-on-Trent, ST4 2DF \\ United Kingdom \\ G.T.Pugh@staffs.ac.uk
}




\begin{abstract}
The contribution of this paper is twofold. First, we use the administrative dataset of the Privatization Agency of Kosovo between 2003 and 2018 to analyze the factors affecting privatization prices. We identify the effects of five sets of variables: features of the auction process; Privatization Agency-related variables; buyer characteristics; asset characteristics; and election-related variables. Second, beyond this econometric investigation, we explore the complexities of the privatization process in Kosovo, in particular the Kosovo-specific factors that may have influenced the prices of privatized enterprises and assets. Policy implications suggest measures to enhance the credibility of the privatization process and related institutions.
\end{abstract}

Key words: Kosovo; privatization prices; socially owned enterprises; auction

JEL: D44; L33; P32 


\section{Introduction}

Following the 1998-99 war and the departure of the Serbian army and administration, Kosovo was left with a shattered economy, severely damaged housing stock and infrastructure and virtually no established institutions. Kosovo became a UN protectorate administered by the United Nations Interim Administration Mission in Kosovo (UNMIK) according to the United Nations Security Council Resolution 1244 . The process of reconstruction, particularly building the new institutional apparatus appropriate for a democratic market economy, including economic institutions, the legal system, law enforcement, banking, etc. began immediately after the war, supported by the UN, the EU and NATO. As in other transition economies (TEs), one of the most important elements of the transformation process was the privatization of socially owned enterprises. The process of privatization and in particular the choice of the method of privatization reflect the complexities arising from the nature of the ownership system in former Yugoslavia, the undeveloped state of institutions and the fact that Kosovo was still formally tied to Serbia. ${ }^{1}$

After much discussion and delay, it was decided that the auction method would be employed as the sole method of privatization. Enterprises were offered for sale (largely) to the highest bidder, a process which started in 2003 and is still continuing though the bulk of enterprises and assets have now completed the process. Although the privatization process in other TEs has been analyzed in great detail, there has been very little discussion of the process and its particularities in Kosovo. Also, although Kosovo is unique in employing auctions as the main privatization method, there has been no study of how prices of companies or assets were determined through the auction mechanism.

The aim of this paper is to address these gaps in the literature by (i) exploring the complexities of the privatization process in Kosovo; and (ii) analyzing the factors affecting privatization prices in the particular conditions of Kosovo. By relying on the literature on the experiences of other countries using the auction method and the specific features of Kosovo's transition, this study identifies five sets of factors that influence the auction prices: specific features of the auction process; characteristics of the assets being auctioned; the role of the privatization agency organizing the auctions; characteristics of buyers; and election related factors. It is important to find out the influence of these factors, particularly those that can be affected by policy makers, so as to maximize the revenue in the interest of creditors, employees and the state.

\footnotetext{
${ }^{1}$ The UNSC Resolution 1244 formally ended Serbian rule in Kosovo with the establishment of the international protectorate. However, the Resolution did not change the borders of the then Federal Republic of Yugoslavia and, therefore, Kosovo remained formally part of Serbia until the declaration of independence in 2008.
} 
We use the complete administrative database of the Privatization Agency of Kosovo, covering the population of privatized assets in the 2003-2018 period. We identify the following positive influences on privatization prices: (i) the number of bidders; (ii) deposit requirements; (iii) the size of land and buildings; (iv) foreign investors; (v) belonging to the manufacturing sector; and (vi) being located in cities. Conversely, the following factors tend to lower auction prices: (i) sale later in the privatization program; and (ii) the duration of the sales process. In addition, although important national influences on privatization prices cannot be explicitly modeled in a single-country investigation, these are nonetheless extensively discussed: the poor state of socially owned enterprises and their assets; contentious ownership rights at the beginning of the process; the weak regulatory and institutional environment; and a privatization process designed to address political concerns of UNMIK officials. A major issue of concern in our regression analysis is the possibility that some of our main variables of interest may be endogenous. For this reason, we include an extended discussion of this issue before reporting our regression results.

The structure of the paper is as follows. Section two discusses the privatization process and its particular complexities in Kosovo. Section three reviews the literature and provides the analytical framework of the paper. Section four discusses the data, the empirical strategy and regression results, paying special attention to the issue of endogeneity. Section five reflects on the Kosovo-specific factors beyond the econometric analysis affecting privatization prices. Section six concludes the paper and offers brief policy recommendations.

\section{Privatization in Kosovo: the context}

In Kosovo, as in other parts of former Yugoslavia, enterprises were "socially owned" (as opposed to being "state owned", typical of other socialist countries). Enterprises belonged to "society" but were entrusted to their employees to manage them on behalf of society and who were expected to maintain them and increase their values on a regular basis. Employees were the main beneficiary of enterprises; they decided on major issues affecting their enterprise and were responsible for the resource allocation process within their enterprise. $^{2}$

The former Yugoslavia was a federation of eight Republics and Autonomous Provinces that were responsible for their own political and socio-economic affairs and the supervision of the independent,

\footnotetext{
${ }^{2}$ For detailed discussion of the social ownership in Yugoslavia and problems associated with it, see among others: Horvat (1982); Lydall (1984); Prout (1985); Hashi (1992); Stiglitz (1995); and Uvalić (1997, 2010).
} 
self- managed enterprises within their territories. The 1974 Constitution gave the eight constituent units of Yugoslavia equal status in the governance of the country as a whole. Although the two Autonomous Provinces of Kosovo and Vojvodina were part of the Socialist Republic of Serbia, for all practical purposes they were independent of Serbia. Most importantly, any change in the constitutional arrangements in Serbia or its two Autonomous Provinces required the agreement of the Assemblies (parliaments) of not just Serbia but also of the two Provinces. ${ }^{3}$

In 1989, Serbia managed to annul Kosovo's autonomy, abolishing its autonomous institutions and taking control of the government, institutions and enterprises. Using laws passed as "temporary measures", it dismissed the majority of Albanian employees and effectively ended the system of self-management in Kosovo. In the following decade Kosovo's economy suffered seriously from lack of investment (indeed, disinvestment), shortage of high skilled employees, and general mismanagement. During this period, shares of many enterprises were transferred to entities in Serbia (usually creditor banks, companies or institutions), something which later contributed to the complexities of the privatization process in Kosovo (see for example the case of the Trepça Mining and Metallurgical Complex in Palairet, 2002).

While assigning clearly defined property rights was the principal argument for privatization in former Socialist countries (Stiglitz, 1995), in the case of Kosovo the ambiguity of social ownership, and the transformations of enterprises by Serbian authorities during the 1990s, raised two critical questions: first, who had the authority to sell the socially owned property - enterprises, employees, or the state (and which state, Kosovo or Serbia); and, second, who was entitled to the proceeds from privatization (the enterprise, the employees or the state)? The international community was concerned that the ambiguities of social ownership and the decade of Serbia's active involvement in the SOE sector in Kosovo, which resulted in Serbian entities having claims against Kosovo enterprises, may generate future claims against the new owners of Kosovo's SOEs. They were also afraid that the sale of Kosovo's SOEs may make international officials and institutions liable for these claims.

Of course, to some extent, the international community was overcautious as other parts of former Yugoslavia (including a few enterprises in Kosovo itself) had already embarked on the privatization process, initially under the Law on Social Capital (1988 and 1989), better known as the Marković Law, and later through their own privatization laws and regulations. The process of privatization (or ownership

\footnotetext{
${ }^{3}$ Numerous articles of the 1974 Constitution of Yugoslavia (for example Articles 2, 4, 5, 171, 246, 321 and 398, and Constitutional Amendments III, IV and XLI) emphasize the autonomous nature and self-management rights of autonomous provinces and their equality with the republics (see Jogoslovenski Pregled, 1989).
} 
transformation) could be initiated by either enterprises themselves or the state and it was also clear that both employees and the state were to benefit from the process. ${ }^{4}$

After two years of deliberation, and faced with the reality that enterprises' conditions were deteriorating by the day, the UNMIK administration decided on a particular method of privatization, direct sale to the highest bidder, and established the institutional framework to transform Kosovo SOEs into private enterprises. ${ }^{5}$ First, at the core of the privatization infrastructure was the Kosovo Trust Agency (KTA), which was established in 2002 as an independent body to 'administer SOEs as a trustee for their owners' and 'carry out ancillary activities to preserve or enhance the value, viability and governance of SOEs' functions similar to those of privatization agencies in other TEs. The KTA was also given the authority to privatize SOEs, either as going concerns with a market value, or otherwise liquidate them and sell their individual assets. The rationale for the establishment of KTA was to sell SOEs and their property/assets, as it was quite obvious that further delays in the transfer of property rights to private investors would deplete further the already depleted stock of SOEs' assets. ${ }^{6}$ Decades of mismanagement and underinvestment in SOEs, particularly in the 1990s, compounded by damage suffered during the war, had enormously reduced the value of enterprises in Kosovo. Hence, the aims of 'enhancing of the value, viability and governance of SOEs' could never be seriously pursued by the Agency. Second, the Special Chamber of the Supreme Court (SCSC) was established as the judicial authority with primary jurisdiction over the creditor and other claims against SOEs or the Agency. ${ }^{7}$ Finally, the proceeds from the sale of each SOE were to be placed in a Trust Fund (in the form of an Escrow account), with $20 \%$ of the sales revenue to be awarded to the former employees ${ }^{8}$ and the rest used to address creditors' claims. ${ }^{9}$ In this

\footnotetext{
${ }^{4}$ See Bayliss (2005); Cerović (2010); Franičević (1999); Gligorov (2004); Slaveski (1997); Uvalić (2010), among others.

${ }^{5}$ As a matter of fact, in the legislation pertaining to the transformation of social property in Kosovo there is no reference to privatization at all. The transformation is done under the notion of "administration" of SOEs (see UNMIK Regulation 2002/12 on the Establishment of the Kosovo Trust Agency (http://www.unmikonline.org/regulations/ unmikgazette/02english/E2002regs/RE2002_12.pdf; accessed on: January 17, 2019). KTA was also responsible for the 'socalled' publicly owned enterprises (POEs), those offering public services (utilities, etc.). After 2008, by Law these enterprises were withdrawn from the Agency and put under the auspices of the Ministry of Economic Development.

${ }^{6}$ With the declaration of independence, the KTA was transformed into the Kosovo Privatization Agency (KPA) with largely the same mandate. Much of the current privatization infrastructure - legal and institutional - is similar to the one establishing KTA. Hence, the designation 'Agency' is used interchangeably for both the KTA and the KPA.

${ }^{7}$ The Special Chamber of the Supreme Court, and indeed the entire process of privatization, have had a heavy international involvement over the years. Eight out of 20 judges sitting on the SCSC were international until June 2018 when the change in the mandate of the European Union Rule of Law Mission in Kosovo (EULEX) saw the withdrawal of international judges from this institution. Until September 2014, the Board of Directors of the Agency - the main decision making body - was comprised of members appointed by international bodies governing Kosovo as well as local representatives, with the former having the right to veto any Board decision. All this was done to preserve the credibility of the privatization process.

${ }^{8}$ The $20 \%$ rule was included as a compensation not for the loss of ownership rights, but for workers' loss of self-management rights.

${ }^{9}$ Also, a portion of the proceeds, currently at 5\%, would go towards maintaining the Agency's operations.
} 
way, potential claims would be assessed and dealt with legally through the SCSC in accordance with the law, while UNMIK or its officials would not be liable for any future claims arising from privatization. During the period of governance by the KTA, the fate of the remaining funds after the employees had been paid and creditor claims settled, was not decided upon. Under current legislation, the remaining funds are to be transferred to the state budget for development projects.

The method of privatization adopted by KTA was direct sale to the highest bidder through a sealed-bid auction. In other transition countries, a wide variety of privatization methods had been used (voucher privatization, management-employee buyout, stock market floatation, direct sale through negotiation with buyers as well as various combinations of these methods). The element of auction was present in some of these methods (Czech and Slovak voucher privatization, auction of small shops in various countries, etc.) but, in Kosovo, it was the only method of sale. The auction method was chosen on the basis of its speed, simplicity and the lower potential for corruption. A further consideration was that, in spite of generally low levels of income, low asset prices and the flow of remittances ensured that a large group of citizens could participate in the process. This method has been shown to be much more effective than, for example the mass privatization method adopted in many countries (Zinnes et al., 2001; Djankov \& Murrell, 2002; Estrin et al., 2009). Privatization methods that resulted in concentrated rather than dispersed ownership led to deeper restructuring of privatized companies and better corporate governance arrangements. In addition, privatization to outside owners was more effective compared to sales to insiders. Furthermore, foreign investors have generally favored the direct sale method of privatization (Goldberg \& Nellis, 2008) - although foreign investors did not actively participate in the process in Kosovo (largely because of the unresolved issue of Kosovo's status in the early stages and the fear of potential claims from Serbia).

The particular mechanism of offering companies for sale was the so-called "spin-off" arrangement. The Agency selected viable SOEs ${ }^{10}$ and converted each of them to one or more new limited liability companies. ${ }^{11}$ The new company inherited all the rights and interests of the old SOE but was not liable for its debts or claims against it. The liabilities remained with the old SOE which effectively became a shell

\footnotetext{
${ }^{10}$ The 'viability' of SOEs was an important factor determining if an SOE would go into privatization in its current form. As Korovilas (2006) explains, the KTA defines an economically viable SOE as one which retains the capacity (i.e. it can utilize a significant proportion of its existing capital) to continue operating profitably in its original line of business. Hence, one would not define SOEs as economically viable if their production cannot be profitably resumed, either because there is no longer a market for the product or because the future profits from the SOE are not sufficient to justify the level of investment needed to overhaul the production process.

${ }^{11}$ SOEs were often converted into more than one new company as many of them were involved in several different unrelated activities with no clear advantage.
} 
company under the administration of the Agency. The Agency then offered the new companies (or individual assets) for sale in public tender auctions on a regular basis - a process that is still continuing. Unlike other countries where shares were auctioned, in Kosovo the company (100\% of shares) was put up for auction as one item and sold to a single private investor - the highest bidder. ${ }^{12}$ The remaining assets of SOEs as well as non-viable SOEs would enter a voluntary liquidation process - which also involved offering individual assets for sale through an auction (in very much the same way as viable companies were). ${ }^{13}$

Altogether, by 2018, around 520 SOEs with over 3,000 assets had entered the privatization process. So far, the break-up of 350 SOEs has given rise to some 750 new companies and 950 individual assets, which have been sold through either the spin-off procedure or voluntary liquidation. Of these new companies, 26 were privatized through special spin-offs (explained in footnote 13). The proceeds from privatization have amounted to around $€ 660$ million while the total cost of the process has been around $€ 114$ million. Over $€ 120$ million have been paid to creditors, while around $€ 110$ million have been distributed to former employees of SOEs. Transfers to the state budget exceed $€ 170$ million by the end of 2018.

Overall, the implementation of privatization through the auction method has to be viewed in the light of Kosovo's post-war conditions and the emerging institutional framework. Indeed, it is likely that the weak institutional framework, under which the privatization was conducted over a decade and a half, significantly limited the overall impact of the process (Riinvest, 2008; Knudsen, 2010). Although the evidence for Kosovo is scarce, the literature on transition economies demonstrates that the success of privatization is conditional on the policy framework and the institutional development of the country (for recent discussion see Estrin \& Pelletier, 2018). For instance, Estrin et al. (2009) find that when privatization was accompanied by complementary reforms it had a positive effect on the level of aggregate output. Zinnes et al. (2001) argue that success of privatization is conditional on improvements in prudential, regulatory, and budgetary institutions. Goldberg and Nellis (2008, p. 349) identify the

\footnotetext{
${ }^{12}$ The legislation of privatization in Kosovo uses the notion of "tender" instead of "auction". However, as "tender" is not a very common concept in auction literature, instead we will be using "auction" throughout the paper.

${ }^{13}$ While this simple "spin-off" mechanism was deemed sufficient for the bulk of Kosovar SOEs, a version of it, the "special spinoff", was used for larger strategic companies. In these cases, the buyer not only had to offer a price for the company but also had to undertake additional commitments such as maintaining the old SOE activity, committing to a minimum amount new investment, or retaining a minimum level of employment. Clearly, here, the criteria for choosing the best buyer involved not only the price they offered but the other commitments they made. The additional commitments were meant to ensure that the new owners of large enterprises would invest a minimum amount in revitalizing and modernizing their enterprise and maintain the level of employment for at least a certain period (usually about three year). As these companies were not privatized on the basis of their price, they are excluded from the empirical analysis. In addition, as the price of these companies was significantly higher than price of other companies or assets, their inclusion would also have distorted the econometric investigation.
} 
protection of property rights, effective regulatory agencies and a competent public administration as the institutions needed for successful privatization.

On a final note, the PAK itself has not been devoid of the constraints typical of the institutional setting in Kosovo. Shortages of human and technical capacities have been prevalent. For many years, coordination with other institutions was almost non-existent. There are indications that the Agency has not been able to resist special interest groups, making it susceptible to corruption and rent-seeking (see Knudsen, 2010). Moreover, the performance of the Agency has been questioned as almost half of the SOE assets (in terms of number not value) are still awaiting the process of sale.

\section{Literature review and analytical framework}

Although the literature on privatization is vast, only a handful of studies have investigated the determinants of privatization prices. Even fewer have explored privatization prices in the transition context. A feature of these studies is the lack of a unified theoretical framework guiding their empirical investigations. The theoretical approach is rather eclectic, with auction theory - in conjunction with competition policy - providing the basis for determinants related to the auction process (Klemperer, 1999, 2004; McAfee \& McMillan, 1987; Milgrom, 1989) while other hypotheses draw on concepts developed in the transition literature, specifically related to the privatization process, industrial development and so forth (for discussion see López-de-Silanes, 1997; Shafik, 1994).

Two early contributions investigate price determination under voucher privatization in the Czech and Slovak Republics. Shafik (1994) analyses the relationship between information and price determination, while Claessens (1995) looks into the relationship between ownership structure and equity prices. The former study explores the impact of two sets of information on price variations of shares: the publicly available information on the enterprise's past performance; and private or "insider" information on the enterprise's prospects. He provides econometric evidence that historical data on the enterprise's past performance explains less than one-third of the variation in price, especially in the early stages of privatization. ${ }^{14}$ The information on the enterprise's future prospects - manifested through the bidding process - explains a much higher proportion of price variation. Other important findings suggest that high rates of profitability, location, and the presence of domestic and foreign strategic investors have positive

\footnotetext{
${ }^{14}$ The remaining differences are attributed to the unofficial sources of information about enterprises' performance obtained prior or during the bidding process.
} 
effects on prices while, on the contrary, the number of employees has a significant negative effect on the prices.

Claessens (1995), on the other hand, relates various indicators of the nature and concentration of ownership to the prices offered in the last bidding round or prices quoted in the secondary markets (e.g. stock exchange). The results show that higher prices are associated with a greater degree of concentration. In addition, as in Shafik (1994), the higher the equity share of strategic owners - domestic or foreign - the higher the price.

More recent contributions study determinants of privatization prices in Mexico (López-de-Silanes, 1997), Turkey (Arin \& Okten, 2003), and Brazil (Santos, 2016). López-de-Silanes (1997) - the most authoritative study on the subject - investigates the determinants of privatization prices on a sample of 236 Mexican companies privatized between 1983 and 1992. Arin and Okten (2003) focus on 68 Turkish companies - largely in the cement sector - privatized between 1989 and 1998, while Santos (2016) utilizes a sample of 118 Brazilian companies privatized between 1991 and 2004. Broadly, to explain the factors that affect privatization prices, these empirical investigations rely on three sets of factors: namely, the impact of firm and industry-specific parameters; the auction process; and prior restructuring experience. The results are generally consistent across the three studies. First, in terms of the auction process, higher competition and the speed of sale are both associated with higher premiums (although, in Arin and Okten, 2003, the latter is statistically insignificant). In addition, limiting the participation of foreign investors in auction procedures reduces the price significantly.

Secondly, regarding firm and industry-specific determinants, variables such as net income, capacity utilization, sales and industry features - e.g., whether state enterprises produce a larger proportion of an industry's output - have a positive impact on net prices (although, in the case of Turkish companies, capacity utilization is statistically insignificant). Moreover, as in the case of companies in the Czech and Slovak Republics, when the bidder(s) bid for a more concentrated stake in a company, the premiums are higher. Finally, contrary to widely held belief, most prior restructuring measures - such as, absorbing debt or implementing various efficiency-increasing programs - do not lead to higher prices. What is worse, the latter may even delay privatization of assets substantially. Lopez de Silanes (1997) and Santos (2016) conclude that measures to improve firms' performance and voluntary labor downsizing schemes fail to raise prices, while restructuring measures - debt absorption and compulsory labor downsizing schemes have a significant negative impact on net revenue from privatization. 
Compared to previous investigations on the determination of privatization prices, our study is narrower in range as it includes primarily a set of variables related to the auction process and almost no information on the past performance of SOEs. As we pointed out, this approach reflects the complexities of the political context of the country and the overall state of SOEs after the war. In this context, the Agency had a single priority, i.e. transforming SOE assets as swiftly as possible, with auctions being the natural choice due to their simplicity and swiftness. The approach taken by the authorities in Kosovo seems to echo the key lesson of privatization according to López-de-Silanes (1997, p.1019): 'do not do too much, simply sell'.

Before we discuss the variables of the model, we look first at the auction process in Kosovo in the light of the auction literature. Kosovo provides a unique example of a privatization program relying almost entirely on this method of sale. Other former Socialist countries, such as Albania, the Czech Republic, Slovakia, and others, used auctions for specific enterprises or industries but largely in combination with other modes of privatization (Korovilas, 2006; Shafik, 1994). The economic benefits of auctions as a means of allocating resources led UNMIK officials in Kosovo to adopt this method of transformation. Boycko, Shleifer, \& Vishny (1994) argue that auctions are one of the most efficient means of allocating assets or shares to those who value them most. In addition, according to them, auctions produce market valuations of assets of enterprises from the start and hence facilitate subsequent trading. Auctions do not require bureaucrats to assign values to companies, thus avoiding arbitrariness, delays, and corruption. Finally, auctions are much less susceptible to corruption and sales to friends at low prices than are other methods of direct sales.

In addition to economic reasons, the political and institutional context was paramount when selecting auctions as the method of sale. This thinking is in line with Klemperer (1999) who argues that the auction process needs to address the wider economic circumstances of the country, particularly the dangers posed by political and administrative pressures. The experience of other TEs offers evidence that politicians and special-interest groups influenced the design of the auction process as in the Czech Republic and the Russian Federation. As Boycko, Shleifer \& Vishny (1994) argue, auctions during Czech and Russian voucher privatizations had to be simplified and adjusted to political reality even when doing so meant violating economic principles of the auction design.

Designing the auction process in itself is a challenge. Stiglitz (1995) explains that the two most important determinants of a successful auction process are ensuring a level playing field for all participants and enhancing the number of bidders in the auction process. The Agency adopted the highest-price sealed-bid 
auction, whereby each bidder independently submits a single bid, without seeing the other bids, through a single round public auction and the shares of the newly established enterprise or asset/s of SOEs undergoing liquidation are sold to the highest bidder. ${ }^{15}$ The design of this type of auction is viewed as a more efficient mechanism than other rationing devices, because it rests largely on the principles of competition policy (Boycko, Shleifer, \& Vishny, 1994). Also, as Klemperer (2004) argues, sealed-bid auctions are preferred as they reduce the likelihood of collusive, predatory, and entry deterring behavior. However, in the case of Kosovo, Korovilas (2006) identifies a number of vulnerabilities of this sale method. First, contrary to Klemperer (2004), he believes that the high degree of uncertainty related to the outcome of the sealed-bid auction increases the temptation for collusive behavior. According to him, the risk of colluding is greater in Kosovo due to the small size of the bidder community. ${ }^{16}$

Second, according to Korovilas (2006, p.345), an even greater danger comes from 'the fear of coercion, where the successful bidder for an SOE is "encouraged" to withdraw his bid in order for the next highest bidder to win the contest'. This was a frequent occurrence, especially in the first decade of privatization. However, in recent years the Agency has tackled this issue by introducing a provision in the legislation requiring that if the highest bidder withdraws, the asset be offered to the subsequent bidders only at the price offered by the highest bidder. Finally, speculative bids - bidding far above the true valuation of the item auctioned - present a grave challenge. In this case the speculative highest bidder has the opportunity to extract payment from the second highest bidder in return for withdrawing his bid. The introduction of an entry fee and deposit requirement by the Agency was aimed at addressing this problem.

Determining the effect of competition on the prices generated by the auction process is one of the objectives of our empirical investigation. In addition to variables capturing the auction process, the model developed here sheds light on four other groups of independent variables:

$$
\text { Price }_{i}=f\left(\text { Auction }_{i}, \text { Asset }_{i}, \text { Agency }_{i}, \text { Buyer }_{i}, \text { Election }_{i}\right)
$$

\footnotetext{
${ }^{15}$ The general rules of the auction (or the tender rules) in Kosovo are provided in PAK's Generic Rules of Tender http://www.pak-ks.org/desk/inc/media/2B6BC80D-5B75-4483-BA9C-9085F150E38A.pdf; accessed on: February 1, 2019). The regulation sets out the procedure for the sale of SOE assets, including conditions and criteria for: (i) submitting bids; (ii) classification and selection of bids; and (iii) signing sale contracts with winning bidders.

${ }^{16}$ Although according to the legislation, participating in the auction is free to all legal and natural persons apart from public institutions, public enterprises, SOEs, and legal and natural persons that have committed criminal offences, the bidder community remains small, especially as the Agency has not been able to attract foreign investors, including a sufficient number of Diaspora investors.
} 
Specifically, the Price of a company or an asset $i$ is a function of a vector of the auction procedures and requirements during the sale of $i\left(\right.$ Auction $\left._{i}\right)$; a vector of characteristics of the new company or asset undergoing auction $\left(\right.$ Asset $\left._{i}\right)$; a set of dummies related to the Agency's operations $\left(\right.$ Agency $\left._{i}\right)$; the characteristics of the buyer $\left(\right.$ Buyer $\left._{i}\right)$; and the potential effect of elections at the time of the sale of each asset $\left(\right.$ Election $\left._{i}\right)$. In addition, we include two sets of dummy variables. First, time dummies to control for otherwise un-modeled systematic influences on prices in particular periods (e.g. institutional and procedural weaknesses in the early years of privatization as well as subsequent simplifications and improvements in administrative procedures). In particular, the year dummies control for asset price inflation, which in the absence of suitable deflators is our preferred strategy. And, second, separate dummy variables for the original SOE of each new company or asset, which control for all time invariant (or, at least, "slowly moving") and otherwise omitted influences on prices arising from the asset(s) having been part of a particular SOE. In the absence of information on the past performance of SOEs (explained below), these SOE dummies control for the history of assets before privatization, in particular their initial conditions with respect to whether SOE assets were being actively used before auction and, if so, their performance as business assets.

Table 1 presents the precise definitions of, together with standard descriptive statistics on, the dependent variable and the independent variables organized according to these five groups. Previous studies looking at the determinants of privatization prices use the so called Privatization $Q$, which is the net present value of the nominal privatization price of an enterprise net of all restructuring costs (see López-de-Silanes, 1997). However, our model does not include any measure of prior restructuring of SOEs, because in Kosovo there was no attempt to overhaul and revive these enterprises prior to privatization. Accordingly, our dependent variable is the nominal price of each asset as registered in the sales contract $\left(\right.$ Price $\left._{i}\right)$.

A point distinguishing privatization in Kosovo from that in other transition economies is the generally very low prices of assets under consideration. The average price of assets, as shown in Table 1, is just over $€ 300,000$. However, even this is rather misleading as the distribution is heavily right-skewed. The median price is $€ 122,111$; around 30 per cent of assets were sold under $€ 50,000$; just over 60 per cent were sold under or equal to $€ 200,000$; and only 7.7 per cent of assets were sold between $€ 1$ million and $€ 5$ million. (The full range of prices is provided in Appendix 1.)

\section{[TABLE 1 HERE]}


The impact of the auction process on price determination is captured through a number of variables: competition in the auction process represented by the number of bidders (no_bidders); the Agency's experience with the auction process (sales_exp); duration of the sale process (sales_duration); deposit requirement (deposit); and preliminary injunction (prel_inj). In line with competition theory, the auction literature - and related studies on the determinants of privatization prices - concludes that greater competition will affect auction prices positively (see López-de-Silanes, 1997). The degree of competition in the auction process is related to the restriction on entry in the auction process. Hence, as a general rule, more bidders and greater ease of entry enhance competition. The Agency, as explained earlier, placed no formal restrictions on auction entrants, apart from restricting some institutions and delinquent individuals or entities from bidding (applied since 2006). Through simple and low-cost entry procedures the Agency strove to make the auction process conducive to a greater number of entrants. However, cases of coercion whereby either the winning bidder is forced to withdraw its bid, or bidders are prevented from entering the auction process altogether, may have affected the competition in the bidding process as well as undermined the legitimacy of the privatization process in Kosovo (see Korovilas, 2006). Our model utilizes the actual number of bidders in the final round of sale for each asset to measure the degree of competition in the auction process.

Both theoretical and empirical work suggest that the level of privatization prices is affected by "learning" and "credibility" effects. Both feed into the effect of experience accumulated over time. López-de-Silanes (1997) argues that countries use learning to sequence the sale of their assets in privatization, starting with companies in more competitive sectors, where there is presumably less room for errors, and at latter stages, when knowledge is accumulated, selling firms in oligopolistic or non-tradable industries where mistakes may be more costly. Further, he suggests that as privatization and its results become better known to the public, "credibility" increases, translating into a willingness to pay higher prices. In terms of sequencing, the Agency first took aim at what were seen as viable companies, leaving the rest of the assets to be sold through the liquidation process. In the first decade of privatization, the Agency transformed the viable assets of former SOEs into over 750 new companies. The process of establishing new companies came to an end in 2013 and, since then, the Agency has only been liquidating the remaining SOE assets. Hence, the fact that the more viable and easily saleable assets (i.e. those without administrative and political constraints) were sold first, followed by less viable assets, may have a bearing on the direction of the effect of experience on prices.

In terms of credibility, the public perception of the Agency has changed significantly over the years. In the early days, the process of transformation was generally supported by the management and employee 
representatives (see Knudsen, 2013). However, over time, the representatives of enterprises and the general public became disillusioned with the process, resisting further transformation and even legally challenging some of the previous decisions on the sale of assets. It seems that the credibility of the Agency or the process has diminished considerably over time. ${ }^{17}$ Our model treats the notion of "learning" and "credibility" as the effect of experience on price determination. It does so in a purely "learning-bydoing" fashion as presented in the micro-literature. Hence, as our measures of experience we adopt the number of assets sold before the case at hand since the beginning of the privatization program (sales_exp).

Another determinant of privatization prices is the speed or swiftness with which the sale or privatization is carried out (sales_duration). The literature on the determinants of privatization prices is ambiguous on the direction of the effect of the speed of sale on the prices obtained, arguing that insiders (i.e. an enterprise's management and employees) may react differently than outside investors to the announcement of sale of the enterprise. In some cases, as López-de-Silanes (1997) argues, the announcement may trigger a change in stakeholders' behavior, leading to lower productivity, lower performance, wage increases, and so on. In these cases, the faster the process of sale takes place the better. In other cases, as other evidence shows, the announcement improves the company's performance. In the case of Kosovo, since most of the enterprises were inactive at the time when the transformation of their assets began, it would not make sense to look for the stakeholders' response to the announcement of sale in the light of performance indicators. However, for Kosovo, it is reasonable to relate the swiftness of the sale to the type of asset sold (we follow this line of thought in our econometric investigation). Even following this reasoning, the relationship between the speed of sale and prices obtained is ambiguous. Generally, assets such as buildings, technology, and related required a faster treatment as they were degrading by the day. On the other hand, the Agency may have considered a slower approach to selling land as the latter generally does not lose value over time. Our duration of sales variable (sales_exp) is measured by the number of days between the first public announcement of the sale and the completion of the sale (i.e. the signing of the contract) and displays a large variation, from over two months to almost a decade and a half (i.e. assets that have gone through a number of rounds of sales and/or sales that were legally challenged by third parties in the SCSC).

\footnotetext{
${ }^{17}$ Recently, Public Pulse, a UNDP publication, presented data showing that the public considers KTA as one of the three most corrupt institutions in Kosovo (see http://www.ks.undp.org/content/kosovo/en/home/operations/projects/democratic governance/PublicPulse.html (Accessed on: February 21, 2019).
} 
On two other auction-related variables in the model, the literature argues that the deposit requirement (deposit) enhances the quality of the auction by filtering out speculative bids and giving certainty to the whole privatization program, hence the effect on prices is expected to be positive (see López-de-Silanes, 1997) ${ }^{18}$ Conversely, preliminary injunction (prel_inj) - an order issued by the Special Chamber at the request of third parties prohibiting the Agency from selling an asset until a ruling is given - is likely to have a negative effect on the prices as it generally increases uncertainty, raising fears of potential buyers that the asset may come with certain liabilities, not only financial.

Further, the model incorporates two buyer-specific variables: first, the presence of foreign buyers in the process of privatization - whether the buyer is foreign or local (buyer_origin); and, second, the buyer's legal status - whether the buyer is a physical person or a legal person (buyer_entity). In the case of the latter, one would assume that due to the capital prowess of legal persons, they would be willing to pay higher prices. In the case of the former, López-de-Silanes (1997) explains that opening the auction process to foreigners should drive up prices through increased competition and reduced scope for collusion. He further argues that insufficient private domestic savings may also be an additional argument in favor of attracting foreigners to bid. The literature argues that foreign investors have generally favored the direct sale method of privatization (see Goldberg \& Nellis, 2008). However, the process of transformation of property in Kosovo did not attract foreign investors in large numbers as in other transition countries. The largest share of FDI has come from Kosovo's Diaspora, who account for over 70 per cent of "foreign" buyers and sales of $€ 57$ million, which is just less than 9 per cent of total sales revenues from privatization (Gashi, 2019). ${ }^{19}$ The perceived political instability, institutional-related constraints, and the unresolved issue of Kosovo's status are serious risks for foreign investors, and even to Diaspora investors.

Due to the lack of data, the model is limited on enterprise-specific variables. While other investigations have used measures of sales, costs, capacity utilization, technology, labor productivity, liabilities, and so on, our model is restricted to variables such as the type of asset (a company, building, land, and combinations thereof), size of land or buildings (land_m2 and building_m2), sector (sector), location (location) and region (region). In terms of theoretical predictions, the size of the asset should have a positive impact on the price, although we allow for this relationship to be quadratic. Next, sector refers to

\footnotetext{
${ }^{18}$ This variable will be discussed in more detail in Section 4.

${ }^{19}$ The variable "buyer_identity" in the database does not distinguish between the Diaspora investors and genuinely "foreign" investors; otherwise we would have included a Diaspora dummy in the regression directly.
} 
the primary activity of the SOE to which an asset belongs, grouped into manufacturing, agriculture, services, and construction. The expected sign of the sector variables is ambiguous. The dummy for location identifies the sold assets' location, either a city or a village. It is expected that assets located in urban areas will fetch higher prices than those located in rural areas. In the case of region, the Agency divides Kosovo into five regions: Prishtina; Mitrovica; Prizren; Peja; and Gjilan.

Finally, a novel feature of this investigation is that we draw on the political business cycles literature (see Drazen, 2002 for a summary) to assess whether the sale of assets has been manipulated to influence election outcomes in Kosovo (e.g. by downward manipulation of prices in return for political and/or financial support). The literature has long identified opportunistic use of fiscal and monetary instruments to improve economic conditions prior to elections to make voters more inclined to vote for the governing party. Recently, Imami et al. (2018) have argued that, in the transition context, opportunistic politicians may also manipulate non-fiscal/non-monetary policy instruments, while Uberti et al. (2019, p.1) report evidence from post-conflict Kosovo (2001-2018) that the pattern of mining-sector licensing is consistent with electoral opportunism 'despite the checks-and-balance mechanisms introduced by Kosovo's international administrators ... to reduce the politicization of licensing'. Accordingly, we control for the possibility that such a political dynamic may be present also in the privatization process. ${ }^{20}$ Uberti et al. (2019, p.1) provide both theoretical motivation and empirical evidence that the issuance of mining licenses displays a statistically significant and economically substantial rise before scheduled elections but no such effect before early (or unscheduled) elections (when unanticipated and tight schedules limit the incumbent's ability to manipulate the allocation of licenses). Accordingly, we specify our model with two dummy variables, both covering asset sales during the two quarters before elections: one for regular or scheduled elections (election_reg), which is expected to show a negative effect if privatization prices are subject to the same dynamics as the issuing of mining licenses; and another for unscheduled elections (election_un), which is not expected to show a significant effect. (Since the end of the war, Kosovo has undergone six elections - three of each type.)

\section{Empirical strategy and results}

\subsection{Data}

\footnotetext{
${ }^{20}$ Board members are nominated by the Government and approved by the Parliament, thus they are virtually "political" appointees. At the time of its establishment, the Agency's Board of Directors - the main decision-making body - was composed of international and local members with internationals being in the majority at least in terms of voting rights. The latter had largely no political affiliations in Kosovo. Only in 2014 did the composition of the Board change to fully local members.
} 
The analysis utilizes the administrative dataset of the Privatization Agency of Kosovo, which contains information on 1,613 SOE assets sold by the Agency between 2003 and 2018 (for details see Table 1). The dataset covers the entire population of assets sold during this period. The empirical analysis excludes assets sold at prices over $€ 5$ million as well as those sold through the special spin-off method (53 altogether). The reason for the former exclusion is the distortion that would be caused by including a few very large values. The second group were excluded because special spin-offs require extended monitoring by the Agency over a number of years (level of investment, employment retention, type of activity, and so on) and also have conditions attached to the sale (which effectively means that the privatization was not complete as the Agency can reclaim the asset if the conditions are not met). ${ }^{21}$ The excluded group have mean and median (€4.06 and $€ 1.72$ million) of a different order of magnitude than those included in the analysis.

The rate of missing observations is relatively small for the variables included in the model. The duration of sales and the number of bidders have a greater share of missing observations relative to the rest, with 7 and 7.6 per cent, respectively. However, the major drawback of the database is its limited scope. As already pointed out, there is no performance-related information for SOEs prior to their transformation.

\subsection{Econometric model}

We use OLS to estimate Eq.1 as a linear model. All continuous variables are specified as natural logarithms (denoted Ln) so that estimated coefficients are to be interpreted as constant elasticities. The high degree of unobserved heterogeneity of assets conditioned the division of the dataset into four subsets based on the type of assets. This strategy was required also because of the persistent evidence of nonlinearities (i.e. uniform and unambiguous failures of the Ramsey Regression Equation Specification Error Test - RESET) when estimating our model on the whole sample, suggesting the possibility of unmodeled structural breaks. Consistent with this evidence, satisfactory model diagnostics (see Table 2) were obtained upon dividing the sample into four groups according to the classification of assets used by the Agency, namely: i) land-only; ii) buildings-only; iii) mixed - assets containing land and buildings; and iv) buildings-only and mixed (i.e. all asset categories except land only).

\subsection{Potential endogeneity}

\footnotetext{
${ }^{21}$ Examples of reclaimed assets include the Grand Hotel and the Magnesite Mine Goleshi.
} 
Before reporting and discussing our regression results, we consider the possibility that some of our main variables of interest may be endogenous, namely: (i) deposit requirement (deposit), which may be thought to depend on the value of assets; (ii) buyer origin (buyer_origin), as foreign investors may be more interested in the more valuable assets; (iii) the duration of the privatization process (sales_duration), which may be inversely related to the value of the asset; and most importantly (iv) the number of bidders (bidders), because more valuable assets may attract more bidders.

The deposit requirement for tendered assets was established with the sole aim of filtering out speculative bids. This was explicitly stated in Article 8, Paragraph 2, of the PAK Generic Rules of Tender that states 'in order to ensure good will of bidders, each eligible bidder must pay the bid deposit, the amount of which is assigned by the Agency, on individual basis for each subsidiary or tendered item'. As a result, the Agency would arbitrarily set the level of deposit high enough to filter out the speculative bids. At the same time, the deposit had to be set at a sufficiently low level not to deter other bidders from the bidding process. Only in late 2016 did the Agency attempt to formalize the process of setting a deposit for an asset. $^{22}$ The methodology relied on the type of asset, location, size, and so on. A trial period proved that the formulae resulted in high levels of deposit requirement, which reduced the number of bidders significantly. The Agency then decided to abandon this provision altogether. In the context of our endogeneity discussion, this shows that it is unlikely that the level of deposit may have given an indication of the value of the asset undergoing the transformation process. In our regression models, the effects of such changes are controlled for by the year dummies.

In the context of Kosovo, the other three variables - buyer's origin, the duration of the sale and the number of bidders - are also unlikely to be endogenous. We explained earlier that minimal levels of commercial activity of SOEs prior to privatization and the absence of any market-based institutions for valuing assets meant that assets presented for privatization could not be valued prior to the sale, by either the Agency or the investor, with any precision. The Agency provided only a basic set of information for each asset undergoing the process, i.e.: asset type, size, location, and other information pertaining to the SOE to which the asset belongs; and type of sale, deposit requirement, and other details of the tendering process. In addition, the Agency calls on potential bidders to conduct due diligence for the SOE or the asset and provides site visits and access to the SOE documentation. ${ }^{23}$ However, on the latter, the Agency warns that most of the information and documentation related to a specific SOE or its tendered asset may have been lost, destroyed or misplaced during the 1990s and the war. In any case, as Shafik (1994)

\footnotetext{
${ }^{22}$ See PAK Sales Procedures amended in September 2016.

${ }^{23}$ See PAK Generic Rules of Tender, Article 5, amended in September 2016.
} 
explains, even if such information were to be available, its worth would be limited in the context of a market economy. Hence, the bidders must have relied more on their own judgment as well as any private information to get some sense of the value of the asset. The absence of information on the value of the assets attenuates the potential endogeneity of these three variables as a major source of estimation bias. Moreover, there are additional theoretical and contextual reasons to treat these three variables as exogenous.

Foreign buyers are normally expected to participate actively in the privatization process and particularly to bid for the more valuable assets. They use their superior knowledge about the true value of a firm and are able to offer higher prices for that firm. In the case of Kosovo, because of the political uncertainty and the pressure from Serbia that it would dispute the legality of the privatization process ${ }^{24}$, foreign buyers were less present than they were in other transition countries. Contrary to privatization in other transition countries, the absence of well-known multinational companies in the privatization of companies in food, drinks, and other industries was noticeable in Kosovo. ${ }^{25}$ Instead, as already mentioned in Section 3, most of the so-called "foreign" buyers were actually members of the Kosovo Diaspora bidding for privatized assets. Diaspora bidders had access to extra resources and were able to offer higher prices for assets than local bidders. Otherwise, factors affecting the entry of these bidders were not different from the factors influencing other bidders. Thus, the potential for endogeneity is much less than if actual "foreign" investors had participated in the process.

The duration of the process may be thought of as an endogeneous variable because the more valuable assets may be sold more quickly. However, in the case of Kosovo, the duration of the auction process was set administratively by the Agency (initially, up to three months and reduced later) while departures from the prescribed duration were caused by ownership, legal and political disputes, leading to intervention by courts or the Board of the Agency and consequent delays to the contract completion. ${ }^{26}$ Hence, in the context of Kosovo, the duration of the privatization process was exogenous with respect to price.

\footnotetext{
${ }^{24}$ Serbia has particularly targeted foreign investors, trying to dissuade them from entering Kosovo. An example of this was the Brezovica Ski Resort where a French investor pulled out of the negotiated privatization process at the final stages due to pressure from Serbia.

${ }^{25}$ The few exceptions of foreign companies participating in the process were related to SOEs under the special spin-off method explained earlier (and which are excluded from this investigation).

${ }^{26}$ For example, in some cases, individuals or groups of people filed complaints against the Agency and halted the process even when the winning bid had been selected in the auction process. In other cases, the Agency would reject the winning bid on the basis of suspected collusion between bidders resulting in lower auction prices. In some cases, the process was prolonged because the asset simply did not attract bidders.
} 
The number of bidders may be considered as potentially endogenous because of simultaneity, i.e. the possibility that not only does the number of bidders influence the auction price but that, reflecting expectations, the asset price may influence the number of bidders. Although this study utilizes the full administrative dataset of the Privatization Agency of Kosovo, this was not designed to encompass variables to serve as instruments to address potentially endogenous variables in a future econometric investigation. Accordingly, we found only one theoretically plausible instrument for the number of bidders in the database: i.e. a dummy variable for whether the auction required bidder prequalification (preq_bidders). ${ }^{27}$ This variable may influence the number of bidders but otherwise has no bearing on the auction price. Hence, it can serve to identify the effect of the number of bidders on the auction price independently from any feedback - via expectations - of the asset price on the number of bidders. However, because this variable is a "weak instrument" - i.e. it is not very strongly correlated with the number of bidders - two-stage least squares estimation is unlikely to yield unbiased estimates. Instead, we use indirect least squares (ILS) estimation, which is appropriate for exactly identified simultaneous equations models. This approach is explained, and its results are presented, in Appendix 2. The ILS estimates of the constant elasticity of price with respect to the number of bidders for each of our four samples yield three with the same sign and order of magnitude as the OLS estimates (reported in Table 2), although only one of these three is statistically significant. These provide some, albeit not strong, evidence that our OLS estimates are not impaired by endogeneity to such an extent as to nullify the conclusion that the number of bidders has a sufficiently substantial positive impact on auction prices to be of interest to policy makers.

This conclusion is strengthened by comparing the broad similarity between our OLS and ILS estimates with similar findings from previous studies that have been able to implement more thorough investigations into the potential endogeneity of the number of bidders. López-de-Silanes (1997) argues that models of price determination may be complicated by the potential endogeneity of three variables: (i) restructuring; (ii) the duration of the privatization process; and (iii) the number of bidders. We now consider to what extent, if any, this study is subject to the same concerns. López-de-Silanes (1997, p.1011) find that 'taking account of the endogeneity of restructuring policies reverses some of the results ... in the one-step (OLS) specification', although this finding is not supported by either Arin and Okten (2003; Table 4b, comparing Columns 4 and 5) or Santos (2016; comparing Tables 4 and 6) whose OLS

\footnotetext{
${ }^{27}$ The "prequalification of bidders" is a process designed to ensure the legality of bidders in the bidding process. The process filters out the physical or legal persons with a criminal past either for general offences or for offences related to the privatization process. In addition, it prohibits bidders that had occupied socially-owned property, those who had infringed upon terms of contract or had an outstanding debt or penalty to the Agency or any enterprise administered by the Agency. As such, this variable is not related to the value of the company and the price it may fetch in the bidding process; i.e., it is an exogenous variable.
} 
and Two-Stage Least Squares estimates yield substantially unchanged estimates of restructuring effects on privatization prices. However, such effects are not applicable in our study, because in Kosovo no restructuring was undertaken prior to privatization, in large part reflecting lack of capacity (World Bank, 2004). The other two variables highlighted by López-de-Silanes (1997) as potentially endogenous - the duration of the privatization process and the number of bidders - do feature prominently in our model. However, the evidence from previous studies suggests that there are no substantial endogeneity biases in the estimated effects of these variables (at least, none that would alter any policy implications). According to the estimates reported by López-de-Silanes (1997, pp.994 and 1001) addressing the potential endogeneity of these variables makes no substantial difference to the estimates. ${ }^{28}$ The same conclusion regarding the duration of the privatization process and the number of bidders is replicated by Santos (2016; comparing Table 4 with Table 6), ${ }^{29}$ while these variables are treated as exogenous by Arin and Okten (2010). Taking into account that endogeneity associated with restructuring is precluded in our study together with lack of evidence from all previous studies that either the duration of the privatization process or the number of bidders are endogenous to an extent that matters, increases confidence that our OLS estimates are reasonable as indicative magnitudes.

Finally, in our empirical strategy we have taken precautionary measures to address the potential endogeneity of these or other variables insofar as this may arise from omitted variables, i.e. unobserved variables that might influence both the dependent variable and one or more independent variables. To this end, we exploit the hierarchical nature of our "pseudo panel" (Antonakis et al., 2010: 1092). Each of the 1,560 observations on privatized assets (Level 1) is nested within one of the 351 state-owned enterprises (SOEs) by which it was previously owned (Level 2). Accordingly, we specify our models with SOE fixed effects, each one of which controls for all the unobserved SOE-invariant effects on auction prices that are common to the assets nested within that SOE (including most of the information made available to investors noted above). Hence, insofar as the value of the assets to be privatized was influenced by the SOE to which it belonged, this value is not part of the idiosyncratic error term but is controlled for together with other sources of unobserved heterogeneity - by fixed effects in the estimated part of the

\footnotetext{
${ }^{28}$ In the case of total length of sale, in the three OLS models the estimates by López-de-Silanes are either -0.0004 or -0.0003 (in both case with a standard error of 0.0001); whereas the three two-step instrumental variables models addressing potential endogeneity yield estimates of either -0.0005 or -0.0006 (in both case with a standard error of 0.0001 ). In the case of the total number of bidders, the three OLS estimates are 0.0846 (SE 0.0239), 0.0880 (SE 0.0206) and 0.0803 (SE 0.0242) and the three two-step estimates are 0.0658 (SE 0.0273), 0.0641 (SE 0.0233) and 0.0631 (SE 0.0234).

${ }^{29}$ In the case of the "total length of the auction", in the two OLS models the estimates are both -0.0004 (in both case with a standard error of 0.0001); whereas the two two-step instrumental variables models addressing potential endogeneity yield estimates of -0.0004 and -0.0003 (in both case with a standard error of 0.0002). In the case of the "Number of bidders", the two OLS estimates are 0.0979 (SE 0.0303) and 0.0989 (SE 0.0292) and the two two-step estimates are 0.1480 (SE 0.0693), 0.1048 (SE 0.0698).
} 
model. We can be reasonably confident that we have fully addressed the problem of omitted variables. The SOE (Level 2) fixed effects address unobserved heterogeneity in auction prices associated with previous ownership and use of assets, although we cannot be certain that this fully accounts for unobserved heterogeneity at the asset level. However, other unobserved influences are controlled by either time dummies (as noted above) or regional and other location dummies (for example, assets taking longer to sell in Serb-majority areas because of local hostility to privatization).

In conclusion, (i) we have established on theoretical and contextual grounds that the variables suspected of potential endogeneity may legitimately be treated as exogenous in our study; (ii) in the case of the number of bidders, we have provided evidence from both within our study and from the wider literature that no major endogeneity bias arises from simultaneity; and (iii) we have explained how we address potential endogeneity arising from omitted variables. In addition we note that, because our database allows us to analyze all of the assets sold in the period under observation, we avoid endogeneity issues associated with sample selection (Arin and Okten, 2003). Accordingly, we return to the discussion of the OLS estimates presented in Table 2.

\subsection{Regression results and discussion}

Table 2 presents regression results from OLS estimation for the four subsets of assets. We report clusterrobust standard errors and note that for each of the four models reported in Table 2 the Ramsey RESET indicates the validity of linear modeling (and, hence, the validity of our statistical inference). Furthermore, each model controls for both group and time unobserved heterogeneity, by using SOE and year dummies. All four models reveal a high degree of fit. The $\mathrm{R}^{2}$ ranges between 0.81 and 0.89 , meaning that in each case between 81 and 89 per cent of variance in prices is explained by the set of independent variables included in the model.

\section{[TABLE 2 HERE]}

In the rest of this Section, we discuss the expected effects of the five groups of variables on price. The Kosovo-specific factors that may have influenced the prices of SOE assets beyond what we have been 
able to measure through regression analysis will be discussed in Section 5. (These cannot be included in the regression analysis, because - by definition - national influences do not vary across observations.)

\subsubsection{The auction process and its features}

The model incorporates five variables related to the features and requirements of the auction process: experience; duration; competition among bidders; deposit requirement; and the assets having been subject to a preliminary injunction. Initially, quadratic terms of the continuous variables were included to model potential non-linear effects; however, none of these proved statistically significant in any of the models estimated and so are not included in the specifications reported in Table 2.

The estimated effect of the experience variable (sales_exp) is negative in all regressions but statistically significant only in the buildings-only regression (Column 2), in which, keeping other variables fixed, a one per cent increase in the number of assets sold decreases the predicted price by an almost equal proportion (i.e. 1.085 per cent). The interpretation of our regression coefficients needs to be mindful of the presence of SOE dummies. Because these capture price variation between assets associated with individual SOEs across the privatization program, the estimated coefficients on our variables of interest capture how the price varies across the different asset sales within individual SOEs. In the case of our sales experience variable, because our measure - the number of previous sales since the start of the privatization program - is time-varying, the presence of year dummies, which capture systematic influences on prices between particular years, means that the coefficient captures the effect within calendar years. The consequently constrained variation of our sales experience variable -i.e. within SOE effects within particular years - may explain the lack of statistical significance of this variable in three of the four estimates. Nonetheless, as anticipated in the literature review (above), the uniformly negative coefficient on experience seems to reflect the effect of the deteriorating quality or the increasing difficulty over time of selling the assets. Accordingly, the Agency's practice of sequencing from more viable and less complicated to less viable and more complicated assets resulted in lower privatization prices over time. This explains why our negative results for the experience variable in the buildings-only regression are at odds with the predictions of the literature. Moreover, while López-de-Silanes (1997) argues that experience will generate price increases through accumulated learning and increased credibility, in Kosovo the public view of the credibility of the privatization process has diminished over time (see earlier discussion); and the way the experience variable is constructed - i.e. the number of previously sold assets since the beginning of the privatization program - may not capture the "learning effect" as discussed in the López-de-Silanes framework. 
As expected, the estimated effect of the duration of the auction process (sales_duration) is uniformly negative across all four regressions but statistically significant only in the buildings-only and mixed assets regressions (Columns 2 and 4). For these types of assets, the coefficients indicate price elasticities of 0.127 and -0.121 , respectively; i.e. keeping other variables fixed, a one per cent increase in the number of days needed to complete the sale contract decreases the predicted price for these assets by a little over a tenth of a percentage point. Other studies reach similar conclusions; i.e., higher prices are associated with greater speed of the process (Arin \& Okten, 2003; López-de-Silanes, 1997; Santos, 2016). However, the explanations for the negative price effects are different. In the other studies in the literature, the duration of privatization has a negative impact on the operating efficiency of the company (as measured by profit, sales, capacity utilization, and productivity) as the incentives of managers and workers collapse with the announcement of sale, thereby lowering the value of the company. In contrast, although such incentives were absent in Kosovo, because the SOEs were largely inactive before the announcement of sale, there are Kosovo-specific reasons why duration is negatively associated with price. First, the persistence of clientelism in Kosovo (Uberti et al., 2019), such that a protracted sale process increases the perceived risk of the playing field being tilted in favor of a "well-connected" buyer which, in turn, gives rise to: (i) selfselection in the sense that some people decide not to enter the process; and (ii) more conservative bids from those who do participate, reflecting the increased risk. Second, the duration of the sale is also indicative of the difficulties of completing the sale of an asset due to claims against it. This also tended to increase the perception of risk among potential buyers, thereby reinforcing the adverse price effects of self-selection and conservative bidding.

The auction literature is consistent on the positive relationship between competition - as measured by the number of bidders - and price. Consistently positive effects of competition on price premiums are found in López-de-Silanes (1997), Arin \& Okten (2003), and Santos (2016). Our regressions likewise produce consistently positive estimates for the effect of competition on privatization prices. All four reported coefficients are statistically significant at the one per cent level (Table 2). Keeping other variables fixed, a one per cent increase in the number of bidders increases the predicted price of assets by between 0.63 and 0.80 per cent.

The final two auction-related variables have the anticipated effects. The deposit requirement (deposit) filters out speculative bids, thereby making the process more credible and resulting in higher prices. We find the effect to be positive and statistically significant at one per cent in all four regressions. The regression results show that a one per cent increase in the deposit required to enter the bidding process triggers an almost uniform increase in the predicted prices for all classes of assets (the estimated effect 
ranges between approximately 0.50 and 0.63 per cent). Conversely, a preliminary injunction ( $\left.p r e l \_i n j\right)$ in the past, as expected, affects prices negatively in all estimated regressions. Once again, we conjecture that the risks associated with assets under court proceedings had a depressing effect on prices. The magnitude of the estimated coefficients is high, ranging between -0.72 and -0.94 . In other words, keeping all else constant, buildings or building and mixed assets (Column 2 and Column 4) with previous preliminary injunction are predicted to fetch between 51.6 and 60.2 per cent lower prices than those not having been subject to court proceedings. ${ }^{30}$

\subsubsection{The Agency-related factors}

For the category of land, prices seem to have been higher during the PAK administration (2008 and after) than during the KTA's (up to 2008). In this instance, keeping other variables fixed, the difference in the price of land during the PAK period is around 160 per cent higher than in the KTA period. Our prior belief was that the asset prices would be higher during KTA times, as the international administration would have ensured a level playing field and thereby instilled certainty into the process. However, the estimated effect on land assets indicates the reverse. This may reflect two different contexts, one during the UN protectorate prior to 2008 and the other the post-independence context. In the early period, which included the immediate post-war years, acute privatization difficulties arising from the poor business environment, shortage of capital and institutional failures at the Agency may have put downward pressure on land prices. Conversely, in the latter period, and against the background of booming construction, partly fuelled by remittances flowing into real estate, land was seen as a safer and more viable option than other investment opportunities.

The dummy variable for assets sold as new companies (mode_newco) compared to liquidated assets is positive, albeit at the 10 per cent level of statistical significance, only for buildings plus mixed assets (Column 4). Assets sold as new companies generate higher prices as they include the most viable assets of SOEs. The estimated coefficient of 0.34 suggests that, in percentage terms, assets sold as new companies fetched over 40 per cent higher prices than liquidated assets. Investigating further the subset of newly established companies - by estimating our fully specified model only for NewCos as the type of asset (presented in Appendix 3) - the results do not show substantial differences compared to the models for

\footnotetext{
${ }^{30}$ The percentage difference has been obtained by exponentiating the coefficient of the dummy variable and subtracting one. All statistically significant dummies were interpreted using this method.
} 
other assets reported in Table $2 .{ }^{31}$ In terms of the auction process, the degree of competition, deposit requirement, and preliminary injunction show the same effects as for other classes of assets. Again, PAK has managed to fetch higher prices for NewCos compared to its predecessor. It terms of asset characteristics, both the size of land and buildings play an important role in determining the prices of privatized assets. Other regression results - for sector, buyer entity, location, and the region - are largely the same as in the regressions discussed so far.

\subsubsection{Buyer characteristics}

The literature shows that opening the auction to foreign bidders translates into higher prices. In the case of Mexico the prices offered by foreign investors were 25 per cent higher than prices offered by locals (López-de-Silanes, 1997). Similar indications of a positive relationship between foreign capital and price premiums are identified by Claessens (1995) in the case of the Czech and Slovak Republics, and Santos (2016) in the case of Brazil. In our study, the coefficients on foreign ownership (buyer_origin) are positive in each of the land (Column 1), buildings (Column 2), and buildings plus mixed-assets regressions (Column 4): "foreigners" have paid 60 per cent more than locals for land and almost 95 per cent more for buildings and for buildings plus mixed assets. However, the magnitude of these estimated effects may reflect (as noted in Section 4.3) the lack of genuinely "foreign" investors and corresponding predominance of the Diaspora in this category of investors. Nonetheless, the cost of the deterrent effect of political instability and poor institutional quality may still be substantial. Finally, we expected legal entities (buyer_entity) to pay higher prices than would physical persons. However, this effect is statistically insignificant in all classes of assets.

\subsubsection{Asset characteristics}

The asset-specific characteristics proved to be relevant in determining asset prices in Kosovo. As expected, all four regressions show that size matters. In the case of land (land_m2), keeping other variables fixed, a one per cent increase in the size of the parcel increases the predicted land price by a quarter of one per cent. Similarly, a one per cent increase in the size of the building (build_m2) corresponds to a price increase of somewhat less than half a per cent. For mixed assets (Column 3 and 4), the magnitude of the coefficient is in-between; a one per cent increase in the size of buildings, keeping

\footnotetext{
${ }^{31}$ In terms of diagnostics, the Ramsey RESET is significant only at the one per cent level in this model ( $\left.\mathrm{p}=0.022\right)$. However, this is to be expected as the NewCos sample - like the whole sample - contains buildings only assets, land only assets, and buildings and land assets, which - as explained above - entails structural discontinuities and consequent evidence of non-linearity.
} 
other variables constant, triggers an increase of around one-third of one per cent increase in the price of assets.

Other variables indicate more or less the expected direction of the effect. Generally, land and buildings of manufacturing SOEs fetch higher prices than do land and buildings belonging to SOEs in agriculture, trade and services, and in some cases also in construction. Next, assets located in a city attract higher prices than assets located in a village. Finally, it is rather interesting that land outside the capital Prishtina attracts significantly higher prices. Indeed, prices of all classes of assets sold in the region of Mitrovica, an industrial hub in former Yugoslav times, exceeded substantially those in the capital.

\subsubsection{Effect of elections}

The coefficients indicating the effect of elections are statistically insignificant for all categories of assets. Hence, these results provide no evidence that the process of sale of former SOE assets was used as a means of achieving political goals at election times. This finding may reflect the fact that the transformation process in Kosovo was under tight control by the international community (at least until 2014). It could also be that the process of sale (from announcement to the completion of sale) is usually prolonged (on average 415 days; see Table 1) and so not susceptible to producing effects to address immediate political objectives.

\section{Determinants of asset prices: looking beyond regression results}

In what follows, we discuss four potential influences on the prices generated during the process of sale, all specific to the Kosovo context: (i) the state of SOE assets at the beginning of the process of transformation; (ii) the specific design of the transformation process to address political considerations; (iii) the weak regulatory and institutional environment, especially law enforcement mechanisms; and (iv) the highly contentious ownership rights prior to the beginning of the process. In the regression analysis, these effects are controlled for: SOE dummies control for the particular state of each SOE's assets; and time dummies control for all systematic but otherwise unmodelled influences on privatization prices in each year from 2003 to 2018, which includes institutional influences. Nonetheless, these dummy variables do not enable us to identify or discuss these influences. This final section goes some way to address this deficiency.

We argued throughout the paper that due to mismanagement, underinvestment, and looting in the 1990s, the value of SOE assets had declined substantially (see Palairet, 2002; Korovilas, 2006; Gashi, 2019). By 
the commencement of privatization in 2003, most SOEs had been inactive or operating at low capacities for up to 15 years. As a result, a large proportion of SOE assets were reduced to real estate property. Hence, prices offered during the bidding process most likely reflected the state of assets and their perceived low market value.

Prices may have been affected by the specific design of the privatization process aimed at addressing the political dispute between Kosovo and Serbia on the issue of SOE ownership. As we pointed out earlier, in order to avoid any future claims against SOEs, Kosovo, and even the UN officials involved in the process of ownership transformation, UNMIK designed the process in a specific manner. It did not "privatize" but rather "transformed" the socially owned property by creating an independent and impartial institutional framework to manage the transformation. However, it ended up with an institutional mechanism that in the early days was completely detached from the rest of the institutional infrastructure in Kosovo and characterized by ineptitude (especially the judicial arm of the process where, to this day, there is still a backlog of over 20,000 cases) as well as by a low level of accountability and transparency. Although the buyers obtained full ownership rights, the Agency did not formally "sell” the SOE assets, instead "renting" them for 99 years. In terms of the impact on prices, this final aspect may have had the biggest influence, as it greatly increased uncertainties and reduced competition in the bidding process. ${ }^{32}$ Moreover, this goes against one of the basic premises of why privatization was needed in former socialist countries, i.e., assigning clearly defined property rights (Stiglitz, 1995).

Further, as pointed out, the process of privatization in Kosovo has been conducted in a poorly developed regulatory and institutional environment. Experiences in other transition countries show that the process of privatization achieved the best results when it was complemented by corresponding policy and institutional reforms (see Estrin et al., 2009; Goldberg \& Nellis, 2008). In the case of Kosovo, weak law enforcement mechanisms coupled with the highly politicized composition of the Agency's Board (particularly, the local members of the Board), created room for corruption and rent seeking. A list of buyers made public by the Agency in early 2016 showed a substantial presence of politicians acquiring former SOE assets. In addition, poor law enforcement meant that many private investors (including from the Diaspora) who bid successfully for SOE assets could not take control of these assets as they were usurped by individuals with strong connections to parties in power or criminal groups. Only in 2017 were almost all the usurped properties brought under the control of their rightful owners. However, the deterrent effect remained strong amongst foreign and Diaspora investors. The small presence of foreign

\footnotetext{
${ }^{32}$ To this day there is no legal clarification concerning what happens after the 99 years run out.
} 
investors in the process of transformation, particularly Diaspora investors - seen as a potential engine of development of Kosovo - reduced substantially the pool of potential bidders and impaired the credibility of the process.

Another impediment to the process of transformation was a result of highly contentious property rights prior to the beginning of the process. This goes beyond the social ownership inherited from former Yugoslavia (see earlier discussion). It rather concerns property transformations that occurred in Kosovo during Yugoslav times and up to the end of the millennium. These complications resulted, first from the nationalization process following the establishment of the Communist regime, and second, from other land swaps that were common during socialist times. In the latter case, for various reasons, land exchanged between public and private owners was usually not recorded in cadastral registers. Cadastral records themselves were another complication of the process of transformation in Kosovo, as the Serbian authorities retained possession of the cadastral books when they left Kosovo in the aftermath of the 1999 war. As a result, especially as there was no "restitution" (returning property to their former owners) by government in Kosovo as there was in other TEs, the transformation of property in Kosovo was bound to face a high degree of ownership claims against former SOE assets. Although the Law governing the privatization process in Kosovo specifies that all claims, including ownership claims, against an SOE or the Agency should be dealt with by the Special Chamber, potential bidders were hesitant to enter the bidding process for such contested properties or else offered lower prices reflecting this uncertainty.

\section{Concluding remarks}

Although the privatization of social property in other transition economies has been studied in great detail, there are only a few studies focusing on the sale prices of privatized assets and almost no systematic study of the privatization process in Kosovo, the last European country to embark on the transition from a socialist to a market economy. This paper explores the rationale for, and the implementation of, the particular method of ownership transformation employed in Kosovo, and identifies the range of factors that influenced the sale price of privatized assets.

The privatization of socially owned enterprises in Kosovo took place in very specific circumstances unlike those in other transition economies. After the war, and with the departure of Serbian forces and administration, Kosovo was left with a shattered economy and infrastructure and the absence of any formal institutions. Initially under the United Nations Interim Administration Mission (UNMIK), and later as an independent country, the economic and political institutions of a democratic market economy 
had to be established afresh and gradually developed. The transition from a socialist to a market economy took place while the relevant institutions were being developed. With much of the enterprise sector lying idle or operating at low capacity, it was recognized that the only way to revive this sector was to transfer the ownership of these companies to the private sector with appropriate incentives to improve their conditions. But "social ownership" as the particular form of ownership inherited from former Yugoslavia, combined with changes in the status and economic conditions of enterprises forced through by the Serbian authorities in charge of Kosovo during the 1989-99 period (which were declared unlawful and discriminatory by UNMIK), meant that the authorities had to formulate a privatization method that would be suitable to these particular conditions. After much discussion, the method of direct sale to the highest bidder through a sealed-bid auction was adopted and, since 2003, over 1600 viable enterprises as well as individual assets of non-viable enterprises have gone through the auction process and transferred to the private sector.

Although the auction method had been used in other transition countries, it was always used in conjunction with other methods. But in Kosovo, auctions were the only method of ownership transformation, providing an opportunity for researchers to investigate the role of auctions and the competitive environment in the privatization process. Using the experience of other countries and the privatization literature in general, we have developed a model of privatization prices incorporating five sets of variables that can potentially influence auction prices: the specific features of the auction process; characteristics of the enterprise or asset being auctioned; the role of the privatization agency organizing the auctions; characteristics of buyers; and election-related factors. We utilize the administrative dataset of the Privatization Agency of Kosovo, covering the whole population of over 1600 enterprises and individual assets that have completed the privatization process, to estimate this model and explore the impact of individual factors.

Given the heterogeneous nature of the assets going through the auctions (ranging from pieces of agricultural land to individual buildings, warehouses, and whole enterprises), the dataset was divided into four groups according to the classification of assets used by the Agency, namely: land-only; buildingsonly; mixed - assets containing land and buildings; and buildings-only and mixed (i.e. all asset categories except land-only). We also consider the issue of the potential endogeneity of some of our variables of interest - in particular the number of bidders - in relation to (i) specifics of the Kosovo context, (ii) our model specification, (iii) comparison of Indirect Least Squares and Ordinary Least Squares estimates, and (iv) evidence from all similar studies. We conclude that in our study the variables of interest may be treated as exogenous and that our OLS estimates are thus valid as indicative magnitudes. 
The model was then estimated for each group separately. Additionally, the model was estimated for assets classified as "new companies". Satisfactory model diagnostics were obtained for all estimated models. The estimated results are, in general, in line with the literature and expectations. Competition in the auction process, represented by the number of bidders, has a consistently positive effect on auction prices across all models. In line with expectation, the estimated effect of the introduction of the deposit requirement proved positive and statistically significant at 1 per cent in all models. Contrary to expectation, the experience accumulated by the Agency was generally associated with lower prices, though significant only in the buildings-only and mixed assets models. This, to a large extent, reflected the fact that more viable, and better quality, assets were offered for sale earlier. Duration of sales, likewise, has a negative effect - assets of lower quality and problematic assets (e.g. those having been subject to court orders at some point) took longer to sell.

The impact of the shift from the Kosovo Trust Agency to the Privatization Agency of Kosovo was rather insignificant in general, except in the "land-only" sample where it was positive and significant. When the asset under the hammer was a new company (as opposed to a liquidated asset), the impact was positive, indicating the better prospect of such assets for bidders.

Regarding bidder characteristics, as expected, foreign investors (mainly from the Diaspora) offered higher prices for most categories of assets, indicating their ability to pay higher prices as well as their expected ability to use the purchased asset more effectively. Regarding asset characteristics, the size of land and buildings had a positive impact on prices. Assets and companies belonging to the manufacturing sector as well as those located in cities attracted higher prices. Finally, contrary to the evidence for some transition economies of microeconomic policies being manipulated for electoral gains by the party in government, elections do not seem to have had any significant effect on privatization prices in Kosovo.

Apart from factors identified in the econometric model, the privatization process, and therefore privatization prices, in Kosovo were affected by the particular conditions characterizing a post-war economy with weak institutions. These included the impact of the poor state of socially owned enterprises and their assets after the war; the contentious ownership rights at the beginning of the process; the weak regulatory and institutional environment, especially the law enforcement mechanisms; and the design of the privatization method aimed at addressing political considerations of UNMIK officials. As this is a single country study, we have been unable to model these contextual influences affecting asset prices. However, although these factors cannot be explicitly included in the model, their influence is reflected in, and controlled for, by the regression constant, a full set of SOE dummies, and the year dummies. 
Our empirical investigation suggests that policy makers should take measures to ensure the credibility of the privatization process, which encourages more bidders and greater competition resulting in higher privatization prices. They should also make greater effort to involve foreign investors, specifically the Diaspora community, which would not only bring additional capital and possibly know-how into the country but would also result in higher asset prices. More broadly, the discussion calls for policy measures to enhance the efficiency of courts dealing with privatization issues; improvement in cadastral records; greater legal clarity of ownership issues; and higher efficiency of the PAK and better interinstitutional coordination to address challenges in the process.

The main limitation of this study is the absence of any information on firm level indicators of the value of assets offered in the auction process (e.g. levels of output, employment, productivity, capital, exports, etc.). This information was simply not available, because in many SOEs production had stopped and/or the records related to the firms' operations had been destroyed or removed to Serbia. Moreover, the institutions that normally enable asset valuation or provide firm-level information (e.g. equity markets, ministries, statistical agencies, etc.) were themselves non-existent. For this reason, the unexpected estimates of the effect of the experience of the privatization agency most likely reflects the omitted quality variable. 


\section{References}

Antonakis, J., Bendahan, S., Jacquart, P. and Lalive, R. (2010). On making causal claims: A review and recommendations. The Leadership Quarterly 21, 1086-1120.

Arin, K. P. and Okten, C. (2003). The determinants of privatization prices: Evidence from Turkey. Applied Economics, 35(12), 1393-1404. https://doi.org/10.1080/0003684032000100391

Bayliss, K. (2005). Post-Conflict Privatization: A Review of Developments in Serbia and Bosnia Herzegovina (ESAU Working Paper No. 12). Retrieved from https://www.odi.org/sites/odi.org.uk/files/odi-assets/publications-opinion-files/2519.pdf

Boycko, M., Shleifer, A. and Vishny, R. W. (1994). Voucher privatization. Journal of Financial Economics, 35(2), 249-266. https://doi.org/10.1016/0304-405X(94)90006-X

Cerovic, B. (2010). Impact of Initial Conditions on Transition Progress: The Case of Montenegro. SouthEastern Europe Journal of Economics, 8(2), 153-169.

Claessens, S. (1995). Corporate governance and equity prices: Evidence from the Czech and Slovak Republics (Policy Research Working Paper No. 1427). World Bank Policy Research Working Paper.

Djankov, S. and Murrell, P. (2002). Enterprise Restructuring in Transition: A Quantitative Survey. Journal of Economic Literature, XL(September), 739-792. https://doi.org/10.2139/ssrn.238716

Drazen, A. (2002). Political Economy in Macroeconomics. Princeton: Princeton University Press.

Estrin, S., Hanousek, J., Kočenda, E. and Svejnar, J. (2009). The Effects of Privatization and Ownership in Transition Economies. Journal of Economic Literature, 47(3), 1-30. https://doi.org/10.1257/jel.47.3.699

Estrin, S. and Pelletier, A. (2018). Privatization in Developing Countries: What Are the Lessons of Recent Experience? The World Bank Research Observer, 33(1), 65-102. https://doi.org/10.1093/wbro/lkx007

Franičević, V. (1999). Privatization in Croatia: Legacies and Context. Eastern European Economics, $37(2), 5-54$.

Gashi, P. (2019). Trade and Industrial Development in Kosovo. In R. Osbild \& W. Bartlett (Eds.), Western Balkan Economies in Transition: Recent Economic and Social Developments (pp. 99121). Cham: Springer International Publishing. https://doi.org/10.1007/978-3-319-93665-9_8

Gligorov, V. (2004). Socialism and the Disintegration of SFR Yugoslavia. In M. Mrak, M. Rojec and C. Silva-Jáuregui (Eds.), Slovenia: From Yugoslavia to the European Union (pp. 15-31). Washington DC: World Bank. 
Goldberg, I. and Nellis, J. (2008). Methods and Institutions - How do They Matter?: Lessons from Privatization and Restructuring in the Post-Socialist Transition. In I. W. Lieberman \& D. J. Kopf (Eds.), Privatization in Transition Economies: The Ongoing Story (pp. 345-370). Amsterdam: Elsevier. https://doi.org/10.1016/S1569-3759(07)00008-3

Hashi, I. (1992). The Disintegration of Yugoslavia: Regional Disparities and the Nationalities Question. Capital \& Class 16(3): 41-88.

Horvat, B. (1982). The Political Economy of Socialism. Oxford: Martin Robertson Press.

Imami, D., Lami, E. and Uberti, L. (2018). Election cycles in mining licensing: Theory and evidence from Albania. Post-Communist Economies, 30(1), 99-116.

Jugoslovenski Pregled (1989). The Constitution of the Socialist Federal Republic of Yugoslavia. Belgrade: Jugoslovenski Pregled.

Kennedy, P. (1985; $2^{\text {nd }}$ Ed.). A Guide to Econometrics. Blackwell: Oxford.

Klemperer, P. (1999). Auction Theory: A Guide to the Literature. Journal of Economic Surveys, 13(3), 227-286. https://doi.org/10.2139/ssrn.172650

Klemperer, P. (2004). Auctions: Theory and Practice. Princeton: Princeton University Press. https://doi.org/10.2139/ssrn.491563

Knudsen, R. A. (2010). Privatization in Kosovo: The International Project 1999 - 2008. Oslo.

Knudsen, R. A. (2013). Privatization in Kosovo: 'Liberal Peace' in Practice. Journal of Intervention and Statebuilding, 7(3), 287-307. https://doi.org/10.1080/17502977.2012.734559

Korovilas, J. P. (2006). Is Privatization in Post-conflict Kosovo Possible? Comparative Economic Studies, 48(2), 326-350. https://doi.org/10.1057/palgrave.ces.8100111

López-de-Silanes, F. (1997). Determinants of Privatization Prices. Quarterly Journal of Economics, CXII(4), 995-1025. Retrieved from https://www.jstor.org/stable/2951264?seq=1\#page_scan_tab_contents

Lydall, H. (1984). Yugoslav Socialism: Theory and Practice. Oxford: Clarendon Press.

McAfee, P. R. and McMillan, J. (1987). Auctions and Bidding. Journal of Economic Literature, 25(2), 699-738. https://doi.org/10.2307/2726107

Milgrom, P. (1989). Auctions and Bidding: A Primer. Journal of Economic Perspectives, 3(3), 3-22. https://doi.org/10.1257/jep.3.3.3 
Palairet, M. (2002). Trepca, 1965-2000. Prishtina.

Prout, C. (1985). Market socialism in Yugoslavia. London: Oxford University Press.

Riinvest. (2008). Post-Privatization in Kosova: Glass Half Empty or Half Full? Prishtina.

Santos, J. E. (2016). Privatization prices: The role of prior restructuring and emerging private ownership structure (mimeo).

Shafik, N. (1994). Information and Price Determination under Mass Privatization. Policy Research Working Paper No. 1305. Washington DC.

Slaveski, T. (1997). Privatization in the Republic of Macedonia: Five Years After. Eastern European Economics, 35(1), 31-51.

Stiglitz, J. E. (1995). Whither Socialism? Cambridge: The MIT Press.

Uberti, L. J., Pugh, G., Lami, E. and Imami, D. (2019). Election cycles and mining-sector governance in post-conflict Kosovo. Post-Communist Economies, 1-23. https://doi.org/10.1080/14631377.2019.1578583

Uvalić, M. (1997). Privatization in the Yugoslav Successor States: Converting Self-management into Property Rights. In M. Uvalic \& D. Vaughan-Whitehead (Eds.), Privatization Surprises in Transition Economies: Employee-Ownership in Central and Eastern Europe (pp. 267-302). Aldershot: Edward Elgar.

Uvalić, M. (2010). Serbia's Transition: Towards a Better Future. New York: Palgrave Macmillan. https://doi.org/10.1360/zd-2013-43-6-1064

Zinnes, C., Eilat, Y. and Sachs, J. (2001). The Gains from Privatization in Transition Economies: Is "Change of Ownership" Enough? IMF Staff Papers No. Vol. 48. Special Issue. 


\section{[APPENDIX 1 HERE]}

APPENDIX 2: ILS and the potential endogeneity of the variable "number of bidders"

The Indirect Least Squares (ILS) approach proceeds as follows. ${ }^{33}$ First, we define two structural equations:

$\mathrm{P}=\mathrm{C}+\beta_{1} \mathrm{~B}+\varepsilon_{\mathrm{P}}$

$\mathrm{B}=\mathrm{C}+\beta_{2} \mathrm{P}+\beta_{3} \mathrm{Pq}+\varepsilon_{\mathrm{B}}$

where $P$ is the natural $\log$ of the price of the asset realized at auction, $B$ is the natural $\log$ of the number of bidders, $P q$ is a dummy variable for whether or not the auction specified bidder prequalification (the identifying variable), $C$ is the usual constant term, and $\varepsilon_{\mathrm{P}}$ and $\varepsilon_{\mathrm{B}}$ the usual error terms. By substituting Eq.2 into Eq.1, and then Eq.1 into Eq.2, we obtain the corresponding reduced form equations:

$\mathrm{P}=\left(\frac{1+\beta_{1}}{1-\beta_{1} \beta_{2}}\right) \mathrm{C}+\left(\frac{\mathrm{B}_{1} \beta_{3}}{1-\beta_{1} \beta_{2}}\right) \mathrm{Pq}+\frac{\beta_{1} \varepsilon_{\mathrm{B}}+\varepsilon_{\mathrm{P}}}{1-\beta_{1} \beta_{2}}$

$B=\left(\frac{1+\beta_{2}}{1-\beta_{1} \beta_{2}}\right) C+\left(\frac{\beta_{3}}{1-\beta_{1} \beta_{2}}\right) P q+\frac{\beta_{2} \varepsilon_{P}+\varepsilon_{B}}{1-\beta_{1} \beta_{2}}$

Denote the compound coefficients on $P q$ in Equations 1' and 2' respectively as $\Pi_{1}$ and $\Pi_{2}$. Then we recover the structural coefficient on $B$ (our potentially endogenous variable in Eq.1) as $\beta_{1}=\Pi_{1} / \Pi_{2}$.

We implement this procedure by (i) augmenting the reduced form equations 1' and 2' with all of the other variables - assumed to be exogenous - included in the models reported in Table 2 and (ii) estimating the two equations jointly as a "seemingly unrelated regression", in order to achieve an efficiency gain by allowing the error terms to be correlated, and with cluster-robust standard errors. We do not report the regressions in full, for reasons of space (although these can be supplied on request). For our largest sample - all assets except land ( $\mathrm{n}=989)$ - in the price equation (1') $P q$ yields - as it should - a small and statistically insignificant coefficient of -0.13 ( $\mathrm{p}=0.687$ ); and in the number of bidders equation (2') the estimate of -0.28 ( $\mathrm{p}=0.156$ ) confirms that $P q$ is at best only a weak instrument. Using these estimates to derive the coefficient on the $\log$ of the number of bidders $(B)$ in the structural equation for the $\log$ of price (the augmented version of Eq.1 above) yields an estimate of the constant elasticity of price with respect to

\footnotetext{
${ }^{33}$ In essentials, the exposition in this paragraph follows Kennedy (1985: 143).
} 
the number of bidders: 0.46 ( $\mathrm{SE}=0.94 ; \mathrm{p}=0.628) .{ }^{34}$ This estimate is not far away from the elasticity estimated by OLS: 0.68 ( $\mathrm{SE}=0.042 ; \mathrm{p}=0.000$; see Table 2). Yet, reflecting the weakness of $P q$ as an instrument for the number of bidders, this ILS estimate cannot be regarded as different from zero at any conventional level of statistical significance (the 95\% confidence interval stretches from -1.39 to 2.30 ).

We repeat this for the other samples and obtain the following ILS estimates of the constant elasticity of price with respect to the number of bidders. For comparison, we add the respective OLS coefficients from Table 2, each of which is statistically significant at the one per cent level.

- ILS. Land only sample ( $\mathrm{n}=447): 0.28$ ( $\mathrm{SE}=1.39 ; \mathrm{p}=0.836)$.

○ OLS: 0.796.

- ILS. Buildings only sample ( $n=489)$ : $-0.03 \quad(\mathrm{SE}=2.29 ; \mathrm{p}=0.988)$.

○ OLS: 0.629 .

- ILS. Land and Buildings sample ( $n=500): 0.93 \quad(S E=0.18 ; p=0.000)$.

○ OLS: 0.644 .

In sum, three from four ILS estimates yield results with the same sign and order of magnitude as the OLS estimates, although only one of these three is statistically significant. The fourth is of the opposite sign (although not significantly so).

\footnotetext{
${ }^{34}$ Calculated by Stata's nlcom command.
} 
[APPENDIX 3 HERE] 
Privatization by Auction: Determinants of Asset Prices in Kosovo

Tables: 
TABLE 1: Definition of variables of the model and summary statistics

\begin{tabular}{|c|c|c|c|c|c|c|c|}
\hline Variables & Var. name & Obs. & Mean & Std. dev. & Min & $\operatorname{Max}$ & Description \\
\hline \multicolumn{8}{|c|}{ Dependent variable } \\
\hline Nominal price & Price & 1,560 & $313,898.9$ & $533,470.9$ & 202 & $4,851,777.0$ & $\begin{array}{l}\text { Privatization price of an } \\
\text { enterprise/asset - the nominal } \\
\text { price of an enterprise/asset in } € \\
\text { as registered in the privatization } \\
\text { contract. Note: as explained in } \\
\text { the text, in the absence of } \\
\text { suitable deflators, the effect of } \\
\text { inflation is controlled by period } \\
\text { dummies. }\end{array}$ \\
\hline
\end{tabular}

\section{Auction related variables}

\begin{tabular}{|c|c|c|c|c|c|c|c|c|}
\hline Sales experience & sales_exp & 1,560 & 820.3 & 464.0 & 0 & 1,612 & $\begin{array}{l}\text { The number of assets sold } \\
\text { before the case at hand since the } \\
\text { beginning of the privatization } \\
\text { program. }\end{array}$ & Ambiguous \\
\hline Number of bidders & no_bidders & 1,442 & 4.6 & 3.8 & 1 & 33 & $\begin{array}{l}\text { Total number of bidders for the } \\
\text { asset in the final round of sale. }\end{array}$ & Positive \\
\hline
\end{tabular}




\begin{tabular}{|c|c|c|c|c|c|c|c|c|}
\hline $\begin{array}{l}\text { Deposit } \\
\text { requirement }\end{array}$ & deposit & 1,441 & $21,813.0$ & $27,410.5$ & 500 & 500,000 & $\begin{array}{l}\text { The deposit required to enter the } \\
\text { auction in } € \text {. }\end{array}$ & Positive \\
\hline $\begin{array}{l}\text { Preliminary } \\
\text { injunction }\end{array}$ & prel_inj & 1,551 & 0.0 & 0.04 & 0 & 1 & $\begin{array}{l}\text { Asset was subject to a } \\
\text { preliminary injunction (Yes }=1 \text {; } \\
\text { No }=0 \text { ). }\end{array}$ & Negative \\
\hline
\end{tabular}

\section{Agency related variables}

$\begin{array}{lccccc}\text { PAK vs. KTA } & \text { pak_vs_kta } & 1,555 & 0.6 & 0.5 & 0 \\ \text { New companies } & \text { newco_liq } & 1,560 & 0.5 & 0.5 & 0 \\ & & & & & \\ \text { Asset under rent } & \text { asset_rent } & 1,560 & 0.3 & 0.5 & 0\end{array}$

The agency in charge of Ambiguous privatization $(\mathrm{PAK}$ in charge $=1$; KTA in charge $=0$ ).

1 Whether the asset was sold as a NewCo or it was liquated $(\mathrm{NewCo}=1$; liquidated assets $=$ $0)$.

1 Asset was/is under rent prior to Positive sale $($ Yes $=1$; No $=0)$.

\section{Buyer characteristics}

$\begin{array}{lccccc}\text { Buyer's origin } & \text { buyer_origin } & 1,560 & 0.04 & 0.2 & 0 \\ & & & & & \\ \text { Buyer's legal status } & \text { buyer_entity } & 1,560 & 0.2 & 0.4 & 0\end{array}$

1 Whether the buyer is foreign or domestic (foreign $=1$; otherwise $=0)$.

Positive

1 Buyer's legal status (legal Positive person $=1$; natural person $=0$ ).

\section{Asset characteristics}




\begin{tabular}{|c|c|c|c|c|c|c|c|c|}
\hline Size of the land & land_m2 & 1,005 & $267,661.5$ & $846,429.4$ & 25 & $1.16 \mathrm{E}+07$ & The size of the land in $\mathrm{m}^{2}$. & Positive \\
\hline Size of the building & building_m2 & 1,080 & $1,950.9$ & $6,278.5$ & 4 & $98,439.00$ & The size of the building in $\mathrm{m}^{2}$. & Positive \\
\hline \multicolumn{9}{|l|}{ Sector of activity } \\
\hline Manufacturing & sector_mnf & 1,560 & 0.2 & 0.4 & 0 & 1 & & \\
\hline Agriculture & sector_agri & 1,560 & 0.3 & 0.5 & 0 & 1 & $\begin{array}{l}\text { Sector of activity of the original } \\
\text { SOE to which the asset belongs. }\end{array}$ & Ambiguous \\
\hline Services & sector_ser & 1,560 & 0.5 & 0.5 & 0 & 1 & & \\
\hline Construction & sector_const & 1,560 & 0.02 & 0.2 & 0 & 1 & & \\
\hline Location & location & 1,560 & 0.7 & 0.5 & 0 & 1 & $\begin{array}{l}\text { Location of the asset (city }=1 \\
\text { village }=0)\end{array}$ & Positive \\
\hline \multicolumn{9}{|l|}{ Region: } \\
\hline Prishtina & region_pr & 1,560 & 0.3 & 0.4 & 0 & 1 & & \\
\hline Mitrovica & region_mt & 1,560 & 0.2 & 0.4 & 0 & 1 & & \\
\hline Prizren & region_pz & 1,560 & 0.2 & 0.4 & 0 & 1 & $\begin{array}{l}\text { Region where the asset is } \\
\text { located. }\end{array}$ & Ambiguous \\
\hline Peja & region_pe & 1,560 & 0.2 & 0.4 & 0 & 1 & & \\
\hline Gjilan & region_gl & 1,560 & 0.2 & 0.4 & 0 & 1 & & \\
\hline \multicolumn{9}{|l|}{ Election Effects } \\
\hline Regular elections & election_reg & 1,560 & 0.1 & 0.2 & 0 & 1 & $\begin{array}{l}\text { Election effects: (sale taking } \\
\text { place two quarters before }\end{array}$ & Negative \\
\hline Unscheduled & election_un & 1,560 & 0.1 & 0.3 & 0 & 1 & election $=1 ;$ otherwise $=0$ ) & Non- \\
\hline
\end{tabular}


Identifying

Variable

Prequalification of preq bidders

bidders
1,551
1 Requirements for bidders' prequalification $(\mathrm{Yes}=1 ; \mathrm{No}=$ 
TABLE 2: Determinants of asset prices

\begin{tabular}{lrrrr}
\hline & & & Mixed \\
Dependent variable: & Land-only & Buildings- & All assets except \\
assets & only assets & $\begin{array}{r}\text { ass only } \\
\text { (buildings } \\
\text { and land) }\end{array}$ & $\begin{array}{r}\text { (Buildings only + } \\
\text { Mixed assets) }\end{array}$
\end{tabular}

\section{Auction related variables:}

Ln sales experience

$\begin{array}{rrrr}-0.062 & -1.085^{* * *} & -0.285 & -0.373 \\ (0.851) & (0.387) & (0.492) & (0.276)\end{array}$

Ln sales duration

$-0.041 \quad-0.127 *$

$-0.251$

$-0.121 * *$

$(0.081)$

(0.073)

(0.200)

$(0.059)$

Ln number of bidders

$0.796^{* * *}$

$0.629 * * *$

$0.644 * * *$

$0.683 * * *$

(0.071)

(0.082)

(0.112)

$(0.056)$

Ln deposit requirement

$0.535^{* * *}$

$0.629 * * *$

$0.492 * * *$

$(0.110)$

$(0.081)$

(0.138)

$0.629 * * *$

(0.068)

Preliminary injunction

$-0.723 * * *$

$-0.744$

$-0.938 * * *$

(Yes = 1) (prel_inj)

$(0.212)$

(0.754)

$(0.278)$

Agency related variables:

PAK vs. KTA (PAK in

$0.950 * * *$

0.589

$-0.551$

$-0.017$

charge $=1)\left(p a k \_v s \_k t a\right)$

(0.197)

$(0.432)$

(0.636)

$(0.361)$

NewCos (new companies $=1$ )

$-0.107$

0.104

0.545

$0.342 *$

$(0.251)$

(0.253)

(0.412)

$-0.203$

Asset under rent $($ Yes $=1)$

0.159

0.065

0.216

0.117

(asset_rent)

$(0.199)$

(0.108)

(0.222)

(0.096)

Buyer characteristics:

Buyer origin (foreign $=1$ )

$0.476^{* *}$

$0.662 * *$

0.563

$0.666^{* *}$

(buyer_origin)

$(0.230)$

$(0.287)$

(0.976)

(0.276)

Buyer entity (legal entity $=1$ )

0.165

$-0.096$

0.154

0.070

(buyer_entity)

(0.143)

(0.161)

(0.089)

\section{Asset characteristics:}

Ln size of land

$0.250 * * *$

0.083

(land_m2)

(0.075)

(0.067)

Ln size of buildings

(build_m2)

$0.414 * * *$

$0.304 * * *$

(0.070)

(0.077)

$0.357 * * *$

(0.037)

Sector 2: agriculture

$-0.184$

$-0.810 * * *$

$-0.141$

$-0.454 * *$

(Base group: manufacturing)

(sector_agri)

(0.164)

(0.200)

(0.335)

(0.216)

Sector 3: trade and services

$-1.617 * * *$

$-0.250 * *$

0.232

0.041 
(Base group: manufacturing)

(sector_ser)

$$
\text { (0.535) }
$$

$-1.226^{*}$

$$
\text { (0.114) }
$$

(0.481)

(0.314)

Sector 4: construction

(Base group: manufacturing)

(sector_const)

$$
\text { (0.695) }
$$

$0.651 * * *$

0.964

0.429

Location $($ city $=1)$

$0.490 * *$

(0.149)

(0.660)

(0.423)

(location)

(0.213)

$0.921 * * *$

$0.716^{* *}$

$0.643 * * *$

(0.193)

Region 2: Mitrovica

(Base group: Prishtina)

(region_mt)

$1.819 * * *$

(0.334)

(0.330)

$2.277 * * *$

(0.241)

$1.520 * * *$

$1.692 * * *$

(0.446)

Region 3: Prizren

0.774

(0.435)

(0.243)

0.144

(Base group: Prishtina)

(region_pz)

$$
\text { (0.477) }
$$

$-0.334$

$-0.331$

(0.450)

Region 4: Peja

(Base group: Prishtina)

(region_pe)

$2.240 * * *$

(0.266)

(0.422)

$0.792 * * *$

$$
\text { (0.776) }
$$

$-0.282 * *$

0.387

(0.185)

Region 5: Gjilan

(Base group: Prishtina)

(region_gl)

$3.007 * * *$

(0.134)

(0.875)

0.392

(0.679)

0.282

0.051

(0.305)

(0.681)

$(0.385)$

\section{Election effects:}

Regular elections

(election_reg)

$-0.085$

(0.557)

0.103

0.000

$-0.028$

Unscheduled elections

0.245

(0.378)

(0.359)

$(0.211)$

(election_un)

(0.230)

$-0.224$

(0.152)

$-0.275$

(0.449)

$-0.147$

(0.128)

Constant

1.862

9.357

6.590

4.766

(6.600)

(3.166)

(4.181)

(2.208)

\begin{tabular}{lrrrr}
\hline Year dummies & YES & YES & YES & YES \\
SOE dummies & YES & YES & YES & YES \\
Observations & 447 & 489 & 500 & 989 \\
Clusters (SOEs) & 95 & 110 & 272 & 299 \\
R-squared & 0.813 & 0.827 & 0.893 & 0.862 \\
Ramsey test (Prob>F) & 0.722 & 0.739 & 0.080 & 0.249 \\
\hline \hline
\end{tabular}

Note: Cluster-robust standard errors in parentheses;

Stars correspond to the following significance levels: $* * * \mathrm{p}<0.01$, ** $\mathrm{p}<0.05$, $* \mathrm{p}<0.1$ 
APPENDIX 1: Descriptive statistics for specific ranges of the asset prices

\begin{tabular}{lrrrrrr}
\hline \hline Price ranges $(\boldsymbol{\epsilon})$ & Obs. & Mean & Median & Std. dev. & Min & Max \\
\hline $0-50,000$ & 464 & 23,343 & 23,338 & 23,338 & 202 & 50,000 \\
$50,001-100,000$ & 217 & 68,866 & 66,100 & 66,100 & 50,010 & 100,000 \\
$100,001-200,000$ & 282 & 139,128 & 135,000 & 135,000 & 100,001 & 200,000 \\
$200,001-500,000$ & 321 & 311,356 & 303,303 & 303,303 & 200,008 & 499,345 \\
$500,001-1,000,000$ & 156 & 689,044 & 679,499 & 679,500 & 501,000 & 952,779 \\
$1,000,001-2,000,000$ & 84 & $1,347,895$ & $1,305,000$ & $1,305,000$ & $1,000,300$ & $1,955,590$ \\
$2,000,001-5,000,000$ & 36 & $2,889,273$ & $2,648,631$ & $2,648,631$ & $2,004,000$ & $4,851,777$ \\
\hline \hline
\end{tabular}


APPENDIX 3: Determinants of prices for new companies (NewCos)

\section{Auction related variables}

Ln sales experience

(sales_exp)

Ln sales duration

(sales_duration)

Ln number of bidders

$0.699 * * *$

(bidders)

Ln deposit requirement

$0.760 * * *$

(deposit)

Preliminary injunction

$-1.865^{* * *}$

$($ Yes = 1) (prel_inj)

Agency related variables

PAK vs. KTA (Yes = 1)

$1.025 * * *$

(pak_vs_kta)

Asset under rent $(\mathrm{Yes}=1)$

0.119

(asset_rent)

\section{Buyer characteristics}

Buyer origin $($ foreign $=1$ )

(buyer_origin)

Buyer entity (legal entity $=1$ )

$0.226^{*}$

(buyer_entity)

\section{SOE/asset characteristics}

Size of land

$2.09 \mathrm{e}-07 * *$

(land_m2)

(1.03e-07)

Size of buildings

$7.35 \mathrm{e}-05^{* * *}$

(build_m2)

(1.87e-05)

Squared size of

buildings (build_m2_sq)

$-6.36 \mathrm{e}-10 * * *$

(1.95e-10)

Sector 2: agriculture

$-0.892 * * *$

(manufacturing $=1)($ sector_agri)

Sector 3: trade and services

$-0.302$

(manufacturing $=1)($ sector_ser)

Sector 4: construction

(manufacturing $=1)($ sector_const)

Location $($ city $=1)$

$0.433^{*}$ 
Region 2: Mitrovica

$($ Prishtina $=1)($ region_mt $)$

Region 3: Prizren

$1.103 * * *$

$($ Prishtina $=1)($ region_pz $)$

Region 4: Peja

$-0.013$

$($ Prishtina $=1)($ region_pe $)$

Region 5: Gjilan

$-0.089$

$($ Prishtina $=1)($ region_gl $)$

\section{Election effects}

Regular elections

(election_reg)

Unscheduled elections

$0.674 * *$

(election_un)

Constant

\begin{tabular}{lr} 
Year dummies & YES \\
SOE dummies & YES \\
Observations & 712 \\
R-squared & 0.796 \\
Clusters (SOEs) & 284 \\
Ramsey test (Prob>F) & 0.022 \\
\hline
\end{tabular}

Note: Cluster-robust standard errors in parentheses;

Stars correspond to the following significance levels: $* * * \mathrm{p}<0.01, * * \mathrm{p}<0.05$, $* \mathrm{p}<0.1$ 